\title{
Simulation of Photovoltaic Thermoelectric Battery Characteristics
}

\author{
A. K. Esman'), G. L. Zykov), V. A. Potachits' ${ }^{1)}$, V. K. Kuleshov' ${ }^{1)}$ \\ ${ }^{1)}$ Belarusian National Technical University (Minsk, Republic of Belarus) \\ (C) Белорусский национальный технический университет, 2021 \\ Belarusian National Technical University, 2021
}

\begin{abstract}
Solar radiation is an environmentally friendly and affordable energy source with high release of energy. The use of a photovoltaic thermoelectric battery makes it possible to increase the efficiency of converting solar and thermal radiation into electrical energy, both on serene and cloudy days. An original battery structure with photovoltaic and thermoelectric converters is proposed. The 3D model of the proposed photovoltaic thermoelectric battery was realized in the COMSOL Multiphysics software environment with the use of a heat transfer module. The simulation was performed for the geographical coordinates of Minsk and taking into account the diurnal and seasonal variations of both the ambient temperature and the power density of the concentrated AM1.5 solar spectrum, the maximum value of which being varied from 1 to $500 \mathrm{~kW} / \mathrm{m}^{2}$. The dependences of the maximum temperature values of the photovoltaic thermoelectric battery and the thermoelectric converters as well as temperature gradient patterns in the thermoelectric converters have been calculated. The dependences of the maximum temperature gradient values inside the thermoelectric converters on the solar power density are obtained. The graphs of the temperature gradients inside the thermoelectric converters of the photovoltaic thermoelectric battery by concentrated solar radiation versus the time of day in the middle of July and January are provided. It is shown that the output voltage increases up to the maximum values of 635 and $780 \mathrm{mV}$, respectively, in January and in July were achieved due to the temperature stabilization of the back side of the external electrodes of the proposed device
\end{abstract}

Keywords: thermoelectric converter on the basis of $\mathrm{CuInSe}_{2}$, numerical simulation, COMSOL Multiphysics, solar radiation concentrator, solar power density, temperature stabilization, temperature gradient, output voltage amplitude

For citation: Esman A. K., Zykov G. L., Potachits V. A., Kuleshov V. K. (2021) Simulation of Photovoltaic Thermoelectric Battery Characteristics. Energetika. Proc. CIS Higher Educ. Inst. and Power Eng. Assoc. 64 (3), 250-258. https://doi.org/10.21122/1029-7448-2021-64-3-250-258

\section{Моделирование характеристик фототермоэлектрической батареи}

\author{
А. К. Есман ${ }^{1)}$, Г. Л. Зыков ${ }^{1)}$, В. А. Потачиц ${ }^{1)}$, В. К. Кулешов ${ }^{1)}$ \\ ${ }^{1)}$ Белорусский национальный технический университет (Минск, Республика Беларусь)
}

Реферат. Солнечное излучение является экологически чистым и доступным источником энергии с высокой энергоотдачей. Использование фототермоэлектрической батареи позволяет увеличить эффективность преобразования солнечного и теплового излучений в электрическую

\begin{tabular}{ll}
\hline Адрес для переписки & Address for correspondence \\
Есман Александр Константинович & Esman Alexander K. \\
Белорусский национальный технический университет & Belarusian National Technical University \\
просп. Независимости, 65, & 65, Nezavisimosty Ave., \\
220013, г. Минск, Республика Беларусь & 220013, Minsk, Republic of Belarus \\
Tел.: +375 17 331-00-50 & Tel.: +375 17 331-00-50 \\
ak_esman@bntu.by & ak_esman@bntu.by \\
\hline
\end{tabular}


в электрическую энергию как в ясные, так и в пасмурные дни. В данной работе предложена оригинальная структура батареи с фото- и термоэлектрическими преобразователями. Трехмерная модель фототермоэлектрической батареи реализована в программном обеспечении COMSOL Multiphysics с использованием модуля «Теплопередача». Моделирование проводилось для географических координат г. Минска с учетом суточного и сезонного изменений температуры окружающей среды и плотности мощности концентрированного солнечного излучения спектра AM1.5, максимальное значение которой варьировалось от 1 до 500 кВт/м². Рассчитаны зависимости максимальных значений температуры фототермоэлектрической батареи, термоэлектрических преобразователей, а также профили распределения градиента температуры в термоэлектрических преобразователях. Получены зависимости максимальных значений градиента температуры внутри термоэлектрических преобразователей от плотности мощности солнечного излучения. Построены графики зависимостей градиентов температуры внутри термоэлектрического преобразователя фототермоэлектрической батареи при воздействии концентрированного солнечного излучения от времени суток в середине июля и января. Показано, что за счет термостабилизации тыльной стороны внешних электродов предложенного устройства удалось достичь увеличения выходного напряжения до максимальных значений 635 мВ в январе и 780 мВ в июле.

Ключевые слова: термоэлектрический преобразователь на основе CuInSe 2 , численное моделирование, COMSOL Multiphysics, концентратор солнечного излучения, плотность мощности солнечного излучения, стабилизация температуры, градиент температуры, амплитуда выходного напряжения

Для цитирования: Моделирование характеристик фототермоэлектрической батареи / А. К. Есман [и др.] // Энергетика. Изв. высш. учеб. заведений и энерг. объединений СНГ. 2021. T. 64, № 3. C. 250-258. https://doi.org/10.21122/1029-7448-2021-64-3-250-258

\section{Introduction}

A special place among alternative and renewable energy sources is occupied by photovoltaic (PV) batteries [1-4] due to their minimal negative impact on the environment. Despite the improvement of the technology for the production of solar cells (SCs) and the manufacture of new structures of semiconductor materials, scientists continue to search for other possibilities for more rational structures and algorithms for the operation of PV batteries. One of the reasons of the decrease in the efficiency of SCs is that part of the absorbed energy is converted into heat, which can lead to overheating of both single SCs and the entire battery; moreover, performance characteristics deterioration and their service life decrease can occur when using solar radiation concentrators [5-7].

The purpose of this paper is to develop and realize a 3D model of the PV thermoelectric battery in the COMSOL Multiphysics software environment, to calculate and evaluate its temperature characteristics and output voltage obtained under conditions of the diurnal and seasonal variations of the ambient temperature and the power density of the concentrated solar radiation. The search for ways to improve the conversion efficiency of solar energy into electric energy has been carried out.

\section{Construction of the photovoltaic thermoelectric battery}

The structure of the proposed PV thermoelectric battery is shown in the Fig. 1 [8]. In it, semiconductor PV cells 1 are interconnected through molybdenum metal layers $5((x=25-90 \mu \mathrm{m}) \times(y=1000 \mu \mathrm{m}) \times(z=700-1000 \mu \mathrm{m})$ 
in size, see Fig. 1, 2), which located at the interface between these elements. Each of the PV cells includes diffusion doped $p$-type 2 and $n$-type 3 silicon layers (the size of each layer is $(x=0.8 \mu \mathrm{m}) \times(y=1000 \mu \mathrm{m}) \times(z=500 \mu \mathrm{m}))$. $\mathrm{TiO}_{2}$ structured dielectric coating $4((x=300 \mu \mathrm{m}) \times(y=1000 \mu \mathrm{m}) \times(z=0.5 \mu \mathrm{m})$ in size $)$ are deposited on the front side of diffusion doped $p$-type and $n$-type silicon layers, as well as on silicon semiconductor material $6((x=298.4 \mu \mathrm{m}) \times(y=1000 \mu \mathrm{m}) \times$ $\times(z=0.5 \mu \mathrm{m})$ in size $)$. Aluminum mirror coatings 7 are located on the front external surface of the metal layers and are optically connected through structured dielectric coatings to the diffusion doped $p$-type and $n$-type silicon layers, as well as to the semiconductor material of PV cells. CuInSe $e_{2}$-based thermoelectric converters 8 with external 10 and internal 11 molybdenum electrodes are thermally connected to the molybdenum metal layers through $\mathrm{Al}_{2} \mathrm{O}_{3}$-based dielectric layers $9((x=27-92 \mu \mathrm{m}) \times(y=1000 \mu \mathrm{m}) \times(z=1 \mu \mathrm{m})$ in size $)$.

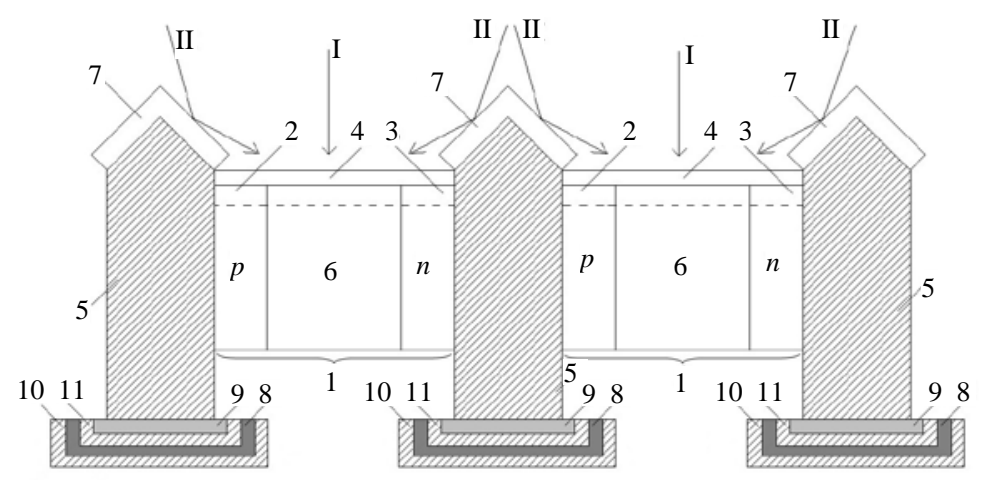

Fig. 1. The photovoltaic thermoelectric battery structure: 1 - PV cell;

2, 3 - diffusion doped $p$ - and $n$-type silicon layers respectively; $4-\mathrm{TiO}_{2}$ structured dielectric coating; 5 - molybdenum metal layer; 6 - silicon semiconductor material; 7 - aluminum mirror

coating; 8 - $\mathrm{CuInSe}_{2}$-based thermoelectric converter; 9 - $\mathrm{Al}_{2} \mathrm{O}_{3}$-based dielectric layer;

10, 11 - external and internal molybdenum electrodes respectively

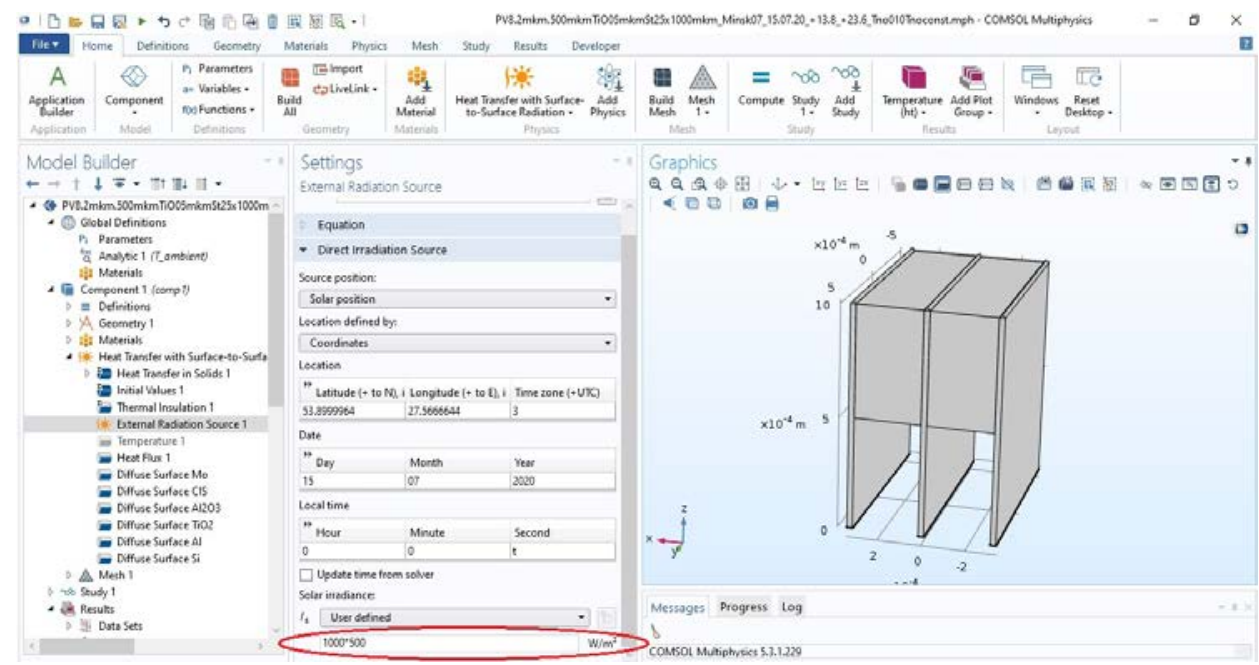

Fig. 2. Screenshot of the setting window of the external radiation source by using the Solar Position option in the COMSOL Multiphysics 


\section{Operation algorithm \\ of the photovoltaic thermoelectric battery}

The PV thermoelectric battery works as follows. The input solar radiation, incident on the surface of the structured dielectric coating, penetrates through it directly (Fig. 1, rays I) and after reflection from the mirror coating (Fig. 1, rays II). Therefore, due to the antireflection effect of the structured dielectric coating, this radiation enters almost completely into the PV cells and is absorbed in them, which causes photogeneration of charge carriers. One part of the generated charges is separated by the fields of the $p-n$ junctions of the PV cells. This leads to the generation of the photo-ElectroMotive Force (photo-EMF). Another part of the generated charges recombines. This provides the heating of the semiconductor material. The thermal energy of the semiconductor material, due to the heat transfer, heats the metal layers in respect of the ambient temperature. As a result, the temperature gradient arises inside the thermoelectric converters, since the external electrodes are kept at the ambient temperature. This causes the appearance of the corresponding thermo-EMF and thereby increases the efficiency of the device.

\section{Computer simulation}

The COMSOL Multiphysics software environment was used to simulate the characteristics of the proposed PV thermoelectric battery. This software environment allows taking into account all of the specified and/or variable parameters when solving most applied problems. The simulation was performed using the heat transfer module of this software environment [9-13], in which the developed numerical model of the PV thermoelectric battery was implemented and its characteristics were calculated in the presence and absence of its temperature stabilization. The presence of the temperature stabilization means that the temperature of the external electrodes 10 is kept equal to the ambient temperature. The calculations were performed for the geographical coordinates of Minsk. The simulation was performed taking into account the diurnal and seasonal variations of both the ambient temperature and the power density of the AM1.5 solar spectrum, the maximum values of which manually ranged from 1 to $500 \mathrm{~kW} / \mathrm{m}^{2}$ (Fig. 2, see area, marked by red ellipse) by using concentrators. In climatology, the diurnal variation of the ambient temperature is usually considered. This diurnal variation is averaged over long-term period, when nonperiodic temperature changes offset each other and the diurnal variation curve of the ambient temperature follows a simple 24-hour periodic sinusoidal distribution around the average temperature:

$$
T_{\text {amb }}(t)=T_{\text {avg }}+\Delta T \cos \left(2 \pi \frac{t-14}{24}\right),
$$

where $T_{a v g}, \Delta T$ stand for two adjustable parameters corresponding to the average temperature and half diurnal temperature variation, respectively; $t$ stands for the variable time in hours. 
The above-mentioned function is used when performing simulation. Average minimum $\left(T_{\text {avg }}-\Delta T\right)$ and average maximum $\left(T_{\text {avg }}+\Delta T\right)$ monthly ambient temperatures data in Minsk were taken from the site: http://belmeteo.net. In addition, the solar radiation incident angles on the battery were determined by the geographic location and time of day [9].

Thus, the PV thermoelectric battery was divided into finite tetrahedral elements in the simulation (Fig. 3). The grid density of each layer was customized by taking into account the tetrahedron geometry by selecting one of the preset modes: from extremely fine to extremely rough. If it is necessary to use a finer grid in any area, the partitioning was performed by manually setting. The program facilities enable to handle and visualize calculated numerical data for all the reviewed operating regimes of the PV thermoelectric battery.

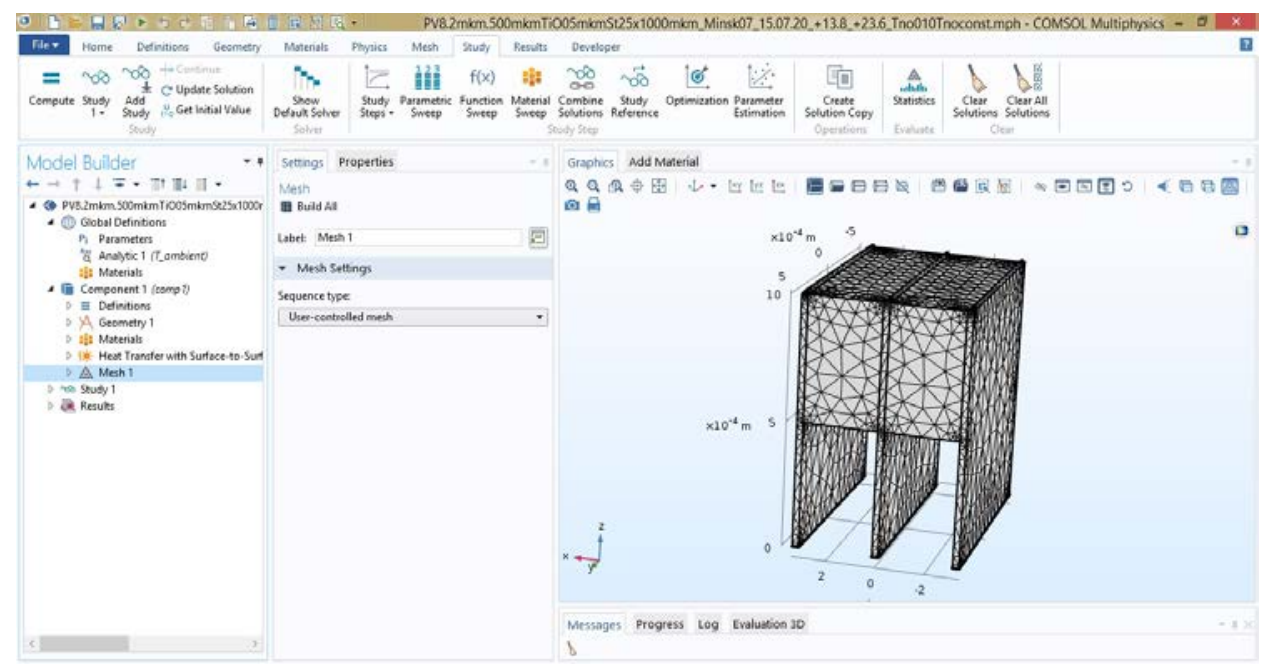

Fig. 3. Screenshot of the mesh operation of the PV thermoelectric battery in the COMSOL Multiphysics

\section{Analysis of the results}

According to the results, the uneven heating of both the surface and internal layers of the PV thermoelectric battery without temperature stabilization occurs during its operation under conditions of diurnal and seasonal variations of the ambient temperature and the solar radiation power density. The increase in the solar power density, the maximum value of which is varied within $1 \mathrm{~kW} / \mathrm{m}^{2} \leq P_{\max } \leq 500 \mathrm{~kW} / \mathrm{m}^{2}$, leads to the temperature variations of the PV thermoelectric battery in the range from $36.5^{\circ} \mathrm{C}$ to temperatures corresponding to its failure. As it follows from [4, 14, 15], the operating temperatures of the PV thermoelectric batteries in various systems can vary from 25 to $60{ }^{\circ} \mathrm{C}$, depending on the used materials, design features and the solar radiation concentration. The temperature stabilization of the back side of the external electrodes of the PV thermoelectric battery at the ambient temperature makes it possible to reduce the operating temperature (up to $+22.8{ }^{\circ} \mathrm{C}$ in January and up to $+48.2{ }^{\circ} \mathrm{C}$ in July at $P_{\max }=500 \mathrm{~kW} / \mathrm{m}^{2}$ (Fig. 4, curve 1) of this battery and, in particular, 
the operating temperature (up to $-0.7{ }^{\circ} \mathrm{C}$ in January and up to $24.7^{\circ} \mathrm{C}$ in July, when $P_{\max }=500 \mathrm{~kW} / \mathrm{m}^{2}$ (Fig. 4, curve 2) of the thermoelectric converter and to increase the temperature gradient (by a factor of 7.6 in July and 10.9 in January, when $P_{\max }=500 \mathrm{~kW} / \mathrm{m}^{2}$ (Fig. 5, curves 2, 2')) inside the thermoelectric converters. It should be noted that a significant temperature gradient occurs inside thermoelectric converters regardless of the ambient temperature (Fig. 6).

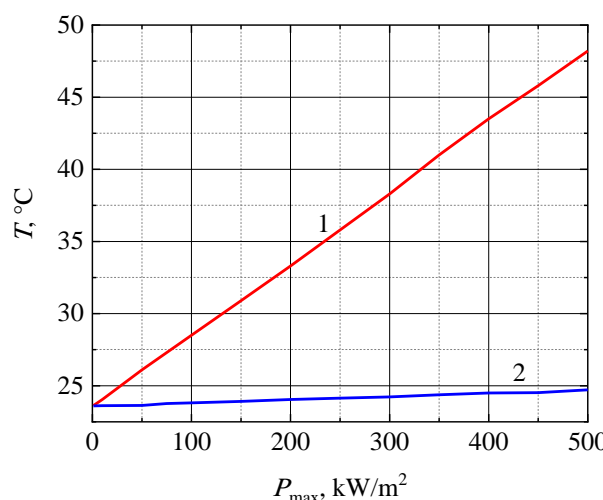

Fig. 4. The maximum operating temperature values of the PV thermoelectric battery (curve 1) and its $\mathrm{CuInSe}_{2}$-based thermoelectric converter (curve 2) in case of the temperature stabilization of the back side of the external electrodes in the middle of July versus the solar power density, the maximum value of which is varied from 1 to $500 \mathrm{~kW} / \mathrm{m}^{2}$

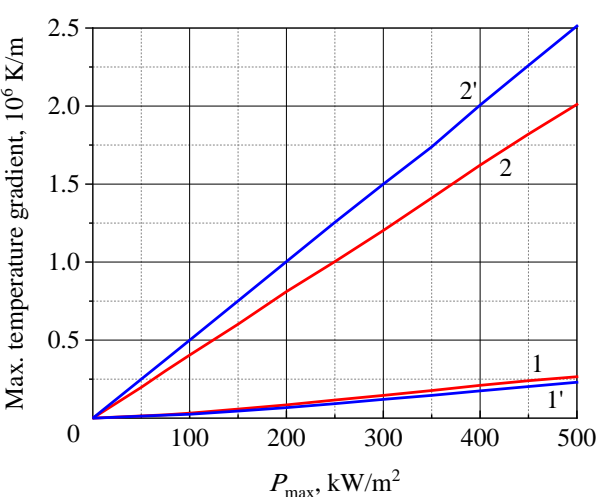

Fig. 5. The maximum values of the temperature gradient inside the thermoelectric converters of the PV thermoelectric battery without (curves 1, 1') and with (curves 2, 2') the temperature stabilization of the back side of the external electrodes in the middle of January (curves 1', 2') and July (curves 1, 2) versus the solar power density, the maximum value of which is varied from 1 to $500 \mathrm{~kW} / \mathrm{m}^{2}$
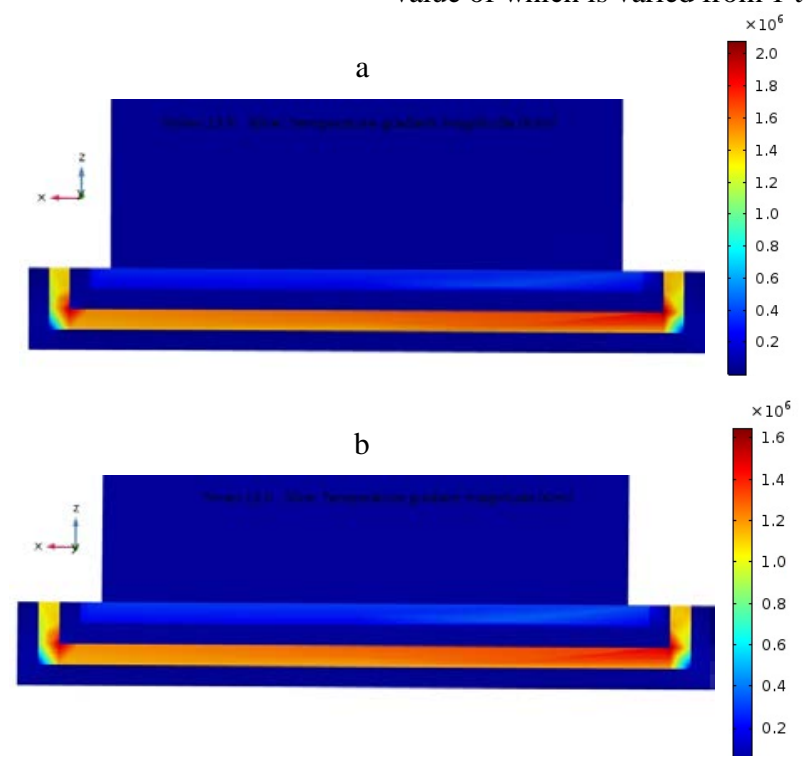

Fig. 6. The temperature gradient patterns inside the thermoelectric converter of the PV thermoelectric battery in one of the cross sections parallel to the $X Z$ plane under concentrated solar radiation conditions with maximum power density of $500 \mathrm{~kW} / \mathrm{m}^{2}$ at 12 o'clock in the middle of: a - January; b - July 
Our calculations allowed us to estimate how much the amount of incident solar radiation on the southeast and southwest sides of the PV thermoelectric battery differs between themselves and from the amount of incident solar radiation on the other sides. At the same time, at about 12 o'clock the southeast side receives this amount of solar radiation, and at about 14 o'clock the southwest side receives this amount of solar radiation. As a result, without taking into account cloudiness, the temperature gradients reach maximum values at the beginning (at about 12 o'clock) on the southeast side and then (at about 14 o'clock) on the southwest side. The temperature gradients are lower by $12 \%$ on the northeast and northwest sides. The dependences of the temperature gradients are presented only for the southeast side of the thermoelectric converters. For all other sides, the dependences of the temperature gradients are similar in appearance, only are shifted in time (northwest and southwest sides) and/or are lower (northeast and northwest sides).

Fig. 7 shows the diurnal changes of the temperature gradients inside the thermoelectric converter of the PV thermoelectric battery under conditions of irradiation of its surface by the concentrated solar radiation with the maximum power density values of 1 and $500 \mathrm{~kW} / \mathrm{m}^{2}$ in July (curve 1) and January (curve 2). As follows from the graphs shown in Fig. 7, the maximum temperature gradient values are reached at about 12 o'clock in the middle of January $\left(2.5 \cdot 10^{6} \mathrm{~K} / \mathrm{m}\right)$ and in the middle of July $\left(2 \cdot 10^{6} \mathrm{~K} / \mathrm{m}\right)$. In January the maximum temperature gradient values are about $20 \%$ higher than in July (Fig. 5, 7), which caused, on the one hand, by the temperature stabilization of the back side of the external electrodes of the PV thermoelectric battery at the ambient temperature, which in January is lower than in July, and, on the other hand, by the concentrated solar radiation exposure on all cells of the PV thermoelectric battery throughout the daylight hours. However, owing to the daylight hours in July are longer than in January, the total energy gain, obtained throughout the day in July, inside the thermoelectric converters of the PV thermoelectric battery is greater than in January.

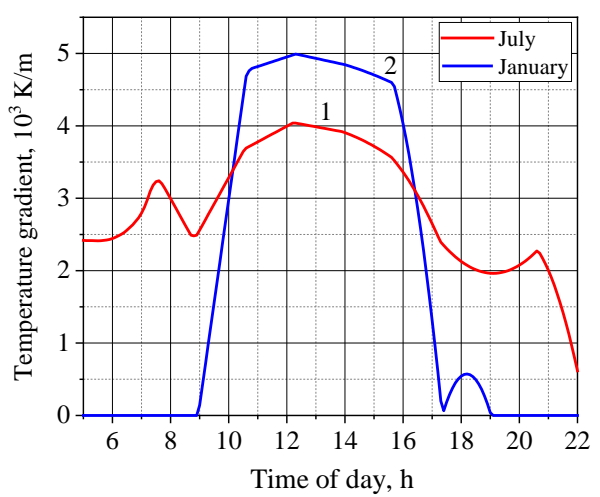

b

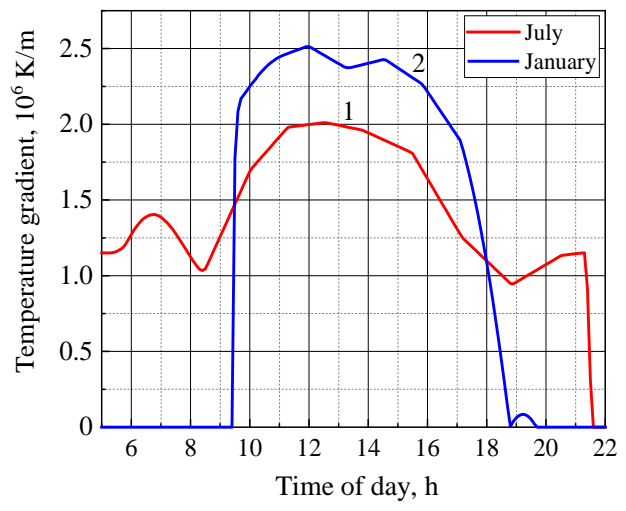

Fig. 7. The temperature gradients inside the thermoelectric converter of the PV thermoelectric battery under exposure of the concentrated solar radiation versus the time of day in the middle of July (curve 1) and in the middle of January (curve 2) with maximum power density: $\mathrm{a}-1 \mathrm{~kW} / \mathrm{m}^{2} ; \mathrm{b}-500 \mathrm{~kW} / \mathrm{m}^{2}$ 
The reached maximum values of the temperature gradients (Fig. 7) between the external and internal electrodes of the thermoelectric converters of the PV thermoelectric battery under exposure of the concentrated solar radiation with maximum power density of $500 \mathrm{~kW} / \mathrm{m}^{2}$ lead to the fact that the potential difference generated between these electrodes in January and July also reaches maximum values of 81.1 and $64.9 \mathrm{mV}$, respectively, at about 12 o'clock. The total generated potential difference throughout the day (at $P_{\max }=500 \mathrm{~kW} / \mathrm{m}^{2}$ ) in the middle of January and in the middle of July is 635 and $780 \mathrm{mV}$, respectively.

\section{CONCLUSION}

The 3D model of the proposed PV thermoelectric battery was developed and realized in the COMSOL Multiphysics software environment. Using this model, the temperature characteristics and output voltages of the proposed PV thermoelectric battery were calculated and evaluated under conditions of the diurnal and seasonal variations of the ambient temperature and the power density of the AM1.5 solar spectrum. In these conditions, the values of the solar power density were varied by using concentrators, and their maximum values were varied in the range from 1 to $500 \mathrm{~kW} / \mathrm{m}^{2}$. The temperature stabilization of the back side of the external electrodes of the PV thermoelectric battery at the ambient temperature makes it possible to reduce the uneven heating of the surface and to reduce the operating temperature of the PV thermoelectric battery (up to $+22.8^{\circ} \mathrm{C}$ in January and up to $+48.2{ }^{\circ} \mathrm{C}$ in July at the maximum value of the concentrated solar power density $P_{\max }=500 \mathrm{~kW} / \mathrm{m}^{2}$ ) and to increase the temperature gradient (by a factor of 7.6 in July and 10.9 in January, when $P_{\max }=500 \mathrm{~kW} / \mathrm{m}^{2}$ ) inside the thermoelectric converters. Calculations have shown that the maximum values of the temperature gradient of the PV thermoelectric battery in January are about $20 \%$ higher than in July. However, the total energy gain, obtained throughout the day in July, inside the thermoelectric converters of the PV thermoelectric battery is greater than in January. In this case, the amplitude of the output voltage generated by the thermoelectric converter reaches maximum values of $81.1 \mathrm{mV}$ (in January) and $64.9 \mathrm{mV}$ (in July) at about 12 o'clock. The total amplitude of the output voltage of the PV thermoelectric battery generated by the thermoelectric converter throughout the day (at $P_{\max }=500 \mathrm{~kW} / \mathrm{m}^{2}$ ) in the middle of January and in the middle of July is 635 and $780 \mathrm{mV}$, respectively. The carried out analysis has shown that under conditions of intense irradiation, the examined PV thermoelectric battery allows not only to increase the energy release per unit area, but also to increase the efficiency.

\section{REFERENCES}

1. Licht A., Pfiester N., DeMeo D., Chivers J., Vandervelde Th. E. (2019) A Review of Advances in Thermophotovoltaics for Power Generation and Waste Heat Harvesting. MRS Advances, 4 (41-42), 2271-2282. https://doi.org/10.1557/adv.2019.342. 
2. Angenendt G., Zurmühlen S., Rücker F., Axelsen H., Sauer D. U. (2019) Optimization and Operation of Integrated Homes with Photovoltaic Battery Energy Storage Systems and Power-to-Heat Coupling. Energy Conversion and Management: X, 1, 100054-1-100054-17. https://doi.org/ 10.1016/j.ecmx.2019.100005.

3. Omair Z., Scranton Gr., Pazos-Outon L. M., Xiao T. P., Steiner M. A., Ganapati V., Peterson P. F., Holzrichter J., Atwater H., Yablonovitch E. (2019) Ultraefficient Thermophotovoltaic Power Conversion by Band-Edge Spectral Filtering. Proceeding of the National Academy of Sciences of the United States of America, 116 (31), 15356-15361. https://doi.org/10.1073/ pnas.1903001116.

4. Vega-Garita V., Ramirez-Elizondo L., Bauer P. (2017) Physical Integration of a PhotovoltaicBattery System: a Thermal Analysis. Applied Energy, 208, 446-455. https://doi.org/10.1016/j. apenergy.2017.10.007.

5. Saxena P., Gorji N. E. (2019) COMSOL Simulation of Heat Distribution in Perovskite Solar Cells: Coupled Optical-Electrical-Thermal 3D Analysis. IEEE Journal of Photovoltaics, 9 (6), 1693-1698. https://doi.org/10.1109/jphotov.2019.2940886.

6. Mamadalieva L. (2020) New Design of the Selective Photothermogenerator with a Fixed Slit. Physics and Mathematics, 9, 1-7. https://www.ukrlogos.in.ua/10.11232-2663-4139.09.14.html (in Russian).

7. Cotfas P. A., Cotfas D. T. (2020) Comprehensive Review of Methods and Instruments for Photovoltaic-Thermoelectric Generator Hybrid System Characterization. Energies, 13 (22), 6045-1-6045-32. https://doi.org/10.3390/en13226045.

8. Esman A. K., Kuleshov V. K., Zykov G. L., Zalesski V. B. (2016) Photovoltaic Thermoelectric Battery: Patent No 19928 Republic of Belarus (in Russian).

9. Thermo-Photo-Voltaic Cell. COMSOL, Inc. USA. Available at: https://www.comsol.com/model/ thermo-photo-voltaic-cell-494 (Accessed 3 February 2021).

10. Analyze Thermal Effects with the Heat Transfer Module. COMSOL, Inc. USA. Available at: https://www.comsol.com/heat-transfer-module (Accessed 3 February 2021).

11. Esman A. K., Kuleshov V. K., Potachits V. A., Zykov G. L. (2018) Simulation of Tandem Thin-Film Solar Cell on the Basis of CuInSe ${ }_{2}$. Energetika. Izvestiya Vysshikh Uchebnykh Zavedenii i Energeticheskikh Ob'edinenii SNG = Energetika. Proceedings of the CIS Higher Education Institutions and Power Engineering Associations, 61 (5), 385-395. https://doi.org/10. 21122/1029-7448-2018-61-5-385-395.

12. Esman A. K., Zykov G. L., Potachits V. A., Kuleshov V. K. (2020) Simulation of Thin-Film Solar Cells with a CuInSe ${ }_{2}$ Chalcopyrite Structure. Energetika. Izvestiya Vysshikh Uchebnykh Zavedenii i Energeticheskikh Ob'edinenii SNG = Energetika. Proceedings of the CIS Higher Education Institutions and Power Engineering Associations, 63 (1), 5-13. https://doi.org/10. 21122/1029-7448-2020-63-1-5-13.

13. Sathya P., Swarna Priya R. M. (2019) Numerical Modeling and Simulation of Thermophotovoltaic Cell using COMSOL. 2019 Innovations in Power and Advanced Computing Technologies (i-PACT). Vellore, 1-5. https://doi.org/10.1109/i-pact44901.2019.8960167.

14. Colangelo G., de Risi A., Laforgia D. (2003) New Approaches to the Design of the Combustion System for Thermophotovoltaic Applications. Semiconductor Science and Technology, 18 (5), S262-S269. https://doi.org/10.1088/0268-1242/18/5/318.

15. Mahamudul H., Rahman Md. M., Metselaar H. S. C., Mekhilef S., Shezan S. A., Sohel R., Karim S. B. A., Badiuzaman W. N. I. (2016) Temperature Regulation of Photovoltaic Module Using Phase Change Material: a Numerical Analysis and Experimental Investigation. International Journal of Photoenergy, 5917028-1-5917028-8. https://doi.org/10.1155/2016/5917028.

Received: 23 February $2021 \quad$ Accepted: 27 April $2021 \quad$ Published online: 31 May 2021 